\title{
SENSING OF PROSTATE SPECIFIC ANTIGEN BY DIFFERENTIAL PULSE ANODIC STRIPPING VOLTAMMETRY OF GOLD NANOPARTICLE - SILVER ENHANCED LABELS
}

\section{Rika Endara Safitri $^{\text {a }}$, Ani Mulyasuryani ${ }^{a^{*}}$, Attasith Parnsubsakul ${ }^{\text {, }}$, and Patsamon Rijiravanich $^{\mathrm{c}}$}

a Jurusan Kimia, Fakultas Matematika dan Ilmu Pengetahuan Alam, Universitas Brawijaya, J1. Veteran Malang 65145, Indonesia

${ }^{b}$ Biological Engineering Program, Faculty of Engineering, King Mongkut's University of Technology Thonburi, Bang KhunThian, Bangkok 10150, Thailand

${ }^{c}$ National Center for Genetic Engineering and Biotechnology, Biochemical Engineering and Pilot Plant Research and Development Unit, King Mongkut's University of Technology

Thonburi, Bang KhunThian, Bangkok 10150, Thailand

* email :mulyasuryani@yahoo.com

DOI : 10.20961/alchemy.v12i2.1724

Received 15 February 2016., Accepted 17 February 2016, Published 01 September 2016

\begin{abstract}
ABSTRAK
Metode deteksi Antigen Spesifik Prostat (ASP) berdasarkan pemotongan peptide dengan menggunakan perak enhancer (AgEhn) pada nanopartikel emas (AuNP) sebagai penanda. ASP merupakan serin protease yang dihasilkan secara normal oleh sel jaringan prostat dan sel kanker prostat. ASP secara luas digunakan sebagai biomarker untuk kanker prostat. Aktivitas ASP dideteksi berdasarkan pemotongan peptida yang terikat pada dasar wellplate melalui interaksi biotin - avidin. Setelah proses pemotongan, peptida-SH yang terpotong akan terbuang dalam proses pembilasan, peptidayang terpotong pada dasar wellplate tidak dapat mengikat nanopartikel emas karena kehilangan gugus tiol (-SH) pada ujung peptida. Sisa peptide-SH yang tidak terpotong akan berikatan dengan AuNP, diikuti dengan reduksi secara autokatalitik pada larutan $\mathrm{AgEhn}$ menjadi $\mathrm{Ag}_{(\mathrm{s})}$. Jumlah $\mathrm{Ag}$ yang terdapat pada permukaan AuNP ditentukan secara voltametri lucutan anodik (VLA) setelah mengoksidasi $\mathrm{Ag}_{(\mathrm{s})}$ menjadi ion $\mathrm{Ag}^{+}$menggunakan elektroda screen printed carbon (SPC). Optimasi dilakukan pada kondisi pengukuran dan kondisi immunoassay, sehingga penentuan PSA pada rentang $1-500$ ng. $\mathrm{mL}^{-1}$ dihasilkan limit deteksi sebesar 152,204 ng. $\mathrm{mL}^{-1}$ dengan sensitivitas $0,003 \mu \mathrm{A} / \mathrm{ng} \cdot \mathrm{mL}^{-1}$. Penentuan PSA dengan metode ini telah berhasil dilakukan, namun masih membutuhkan kajian lebih lanjut.
\end{abstract}

Kata Kunci : antigen spesifik prostat; nanopartikel emas; peptida; voltametri lucutan anodic

\begin{abstract}
A sensitive prostate specific antigen (PSA) detection method based on peptide cleavage and silver enhancement of gold nanoparticle (AuNP) has been developed. PSA is serine protease produced by both normal prostate glandular cells and prostate cancer cells. PSA widely used as a biomarker for prostate cancer (PCa). The activity of PSA was
\end{abstract}


detected by following mechanism: first, some immobilized peptide on the bottom of wellplate was undergo cleaving process via biotin-avidin interaction, leaving short peptide (without thiol group) that could not form a link with gold nanoparticle. Meanwhile, the remaining peptide which not undergo such process could self-assemble with AuNPs, followed by autocatalytic reduction with silver enhancement solutions to silver metal (Ag). The Ag content on AuNPs was determined by differential pulse anodic stripping voltammetry, after axidation of $\mathrm{Ag}$ metal to $\mathrm{Ag}^{+}$ions, using screen printed carbon electrode. The measurement conditions and immunoassay components had been optimized in this study. The detection of PSA was successfully carried out by this method with limit detection value of $152.204 \mathrm{ng} / \mathrm{mL}$, but further development is necessary to improve the limit detection value.

Keywords: anodic stripping voltammetry, gold nanoparticle, peptide, prostate specific antigen,

\section{PENDAHULUAN}

Metode analisis elektrokimia telah banyak dikembangkan di bidang biokimia. Metode elektrokimia dalam analisis biokimia secara umum dikombinasikan dengan metode immunoassay termodifikasi baik pada wadah pengukuran maupun pada elektroda kerja yang digunakan. Penggabungan metode immunoassay dengan metode elektrokimia akan menghasilkan pengukuran yang lebih spesifik dengan batas deteksi yang rendah. Pada penelitian ini, analisis biokimia secara elektrokimia dilakukan pada analisis kanker prostate yang berdasarkan konsentrasi Antigen Spesifik Prostat (ASP).

ASP merupakan enzim serin protease berukuran $30 \mathrm{kDa}$ yang diproduksi secara normal oleh sel epitel prostat dan sel kanker prostat.ASP secara umum digunakan sebagai biomarker dari kanker prostat. Beberapa penelitian tentang penentuan ASP secara elektrokimia yang telah dilakukan, antara lain menggunakan elektroda kerja emas dengan penanda ferosen $\left(\mathrm{Fe}\left(\mathrm{C}_{2} \mathrm{H}_{5}\right)_{2}\right)$ (Zhao et al., 2010) yang menghasilkan batas deteksi 0,2 ng.mL ${ }^{-1}$, dan menggunakan penanda ion ferrosianida $\left(\left[\mathrm{Fe}(\mathrm{CN})_{6}\right]^{4-}\right)$ (Suaifan et al., 2012) menghasilkan batas deteksi hingga 1 pg.mL ${ }^{-1}$. Pada penelitian ini, penentuan ASP menggunakan metode voltametri denyut diferensial lucutan anodic (VDDLA) dengan penanda nanopartikel emas. Metode VDDLA memiliki sensitifitas hingga konsentrasi $10^{-9}$ (ppb).

Beberapa analisis biokimia yang telah dilakukan dengan metode voltametri denyut diferensial (VDD) menggunakan emas sebagai penanda, berupa nanopartikel maupun sebagai elektroda kerja telah banyak digunakan, karena emas dapat berinteraksi dengan gugus tiol (SH) pada peptida (Ambrosi, 2007 dan Al-Akraa et al., 2013). Analisis senyawa biokimia secara VDD menggunakan emas, antara lain dalam penentuan $\alpha$ - fetoprotein 
(Liu et al., 2010); Immunoglobulin G / IgG (Cui et al., 2008; Selvaraju et al., 2008); Thrombin (Zheng et al., 2007); Hepatitis B / HBsAg (Liang et al., 2005); oligonukleotida DNA (Cai et al., 2002; Lu et al., 2004; Kang et al., 2007); serta antigen Karsinoembrionik (Wu et al., 2006).

Penentuan ASP pada penelitian ini menggunakan metode VDD dengan elektroda karbon dan penanda nanopartikel emas (AuNP). Untuk meningkatkan kuantifikasi pada pengukuran secara VDD, penanda AuNP dilapisi dengan senyawa enhancer berupa perak enhancer (AgEhn). AgEhn mudah tereduksi secara enzimatis pada permukaan $\mathrm{Au}$, sehingga penentuan ASP berdasarkan konsentrasi perak (Ag) yang terukur sebagai ion $\mathrm{Ag}$ $\left(\mathrm{Ag}^{+}\right)$. Konsentrasi Ag yang tereduksi pada permukaan AuNP akan dipengaruhi oleh waktu deposisi AgEhn (Morphew et al., 2008).

AgEhn mudah larut dalam pelarut asam (seperti asam nitrat) membentuk ion perak $\left(\mathrm{Ag}^{+}\right)$sehingga mudah diukur secara VDD. Pada penelitian ini, metode VDD dirangkaikan dengan metode prekonsentrasi voltametri lucutan anodik (VLA) untuk meningkatkan sensitifitas pengukuran hingga $\mathrm{ppb}$. Penentuan ASP secara tidak langsung dengan memodifikasi metode immunoassay pada wellplate dan pengukuran secara voltametri denyut diferensial lucutan anodik (VDDLA) didasarkan pada jumlah substrat yang tidak terpotong oleh ASP serta mengikat penanda AuNP - AgEhn. AgEhn yang terikat pada substrat dioksidasi menjadi ion $\mathrm{Ag}^{+}$yang terukur secara VDDLA menghasilkan arus ion perak (Arus $\mathrm{Ag} / \mathrm{I}_{\mathrm{Ag}}$ ), sedangkan jumlah substrat yang tidak bereaksi dengan ASP ditentukan dari selisih arus puncak Ag (Ip PSA $0 \mathrm{ng}^{-1} \mathrm{~mL}^{-1}$ Ip PSA $100 \mathrm{ng}^{-1} \mathrm{~mL}^{-1}$ ). Tujuan dari penelitian ini adalah untuk mengetahui kondisi pengukuran (potensial deposisi, waktu deposisi, dan laju pembacaan) larutan $\mathrm{AgNO}_{3}\left(\mathrm{Ag}^{+}\right)$dengan metode VDDLA dan mempelajari pengaruh komponen immunoassay terhadap penentuan ASP (konsentrasi avidin, konsentrasi BSA, waktu inkubasi peptida, dan waktu deposisi AgEhn) dengan metode VDDLA menggunakan penanda AuNP-AgEhn. Penelitian ini diharapkan dapat menjadi salah satu pengembangan dalam penentuan ASP secara voltametri dengan menggunakan nanopartikel emas - perak enhancer (AuNP - AgEhn) sebagai penanda dalam modifikasi immunoassay yang selektif dan sensitif.

\section{METODE PENELITIAN}

\section{Bahan}

Avidin dari putih telur, Tris(2-karboksietil)fosfin hidroklorida (TCEP) 0,5 M, Larutan Perak Enhancer A, dan Larutan Perak Enhancer B berasal dari SIGMA Life 
Science. Bovine serum albumin (BSA) fraksi V pH 7,0 diproduksi oleh PAA The Cell Culture Company (Austria). Peptida dengan rantai MPA - HSSKLQ - Lis - spacer biotin diproduksi oleh Proteogenix SAS (France). Antigen spesifik prostat (ASP) terbuat dari air mani manusia diproduksi oleh Merck EMD Milipore (USA). Nanopartikel Emas terbuat dari $\mathrm{HAuCl}_{4} 5 \mathrm{mM}$ dari MERCK. Sodium nitrat $\left(\mathrm{NaNO}_{3}\right)$, sodium asetat $\left(\mathrm{NaCH}_{3} \mathrm{COO}\right)$, asam asetat $\left(\mathrm{CH}_{3} \mathrm{COOH}\right) 100 \%\left(\rho=1,050 \mathrm{Kg} \cdot \mathrm{L}^{-1}\right)$, sodium karbonat $\left(\mathrm{Na}_{2} \mathrm{CO}_{3}\right)$, sodium hidrogen karbonat $\left(\mathrm{NaHCO}_{3}\right)$, di-sodium hidrogen fosfat $\left(\mathrm{Na}_{2} \mathrm{HPO}_{4}\right.$. $\left.2 \mathrm{H}_{2} \mathrm{O}\right)$, sodium dihidrogen fosfat $\left(\mathrm{NaH}_{2} \mathrm{PO}_{4} \cdot \mathrm{H}_{2} \mathrm{O}\right)$, asam nitrat $\left(\mathrm{HNO}_{3}\right) 69 \%$, hidrogen klorida (HCl) 37\%, dantris-hidrogenmetilaminometan (TRIS) diproduksi oleh MERCK. Semua larutan disiapkan dengan air MiliQ. Elektroda Screen-printed carbon (SPCE) C$\mathrm{Ag} / \mathrm{AgCl}$ (BI 1302) diproduksi oleh Quasense.co.Ltd (Karbon sebagai elektroda kerja; $\mathrm{Ag} / \mathrm{AgCl}$ sebagai elektroda acuan danelektroda pembanding), 96 wellplate maxisorp (442404) diproduksi oleh Thermo Scientific NUNC plate (Denmark).

\section{Alat}

Peralatan eletroanalisis yang digunakan adalah Autolab ( PGSTAT 12 serial no.AUT 71393 dengan perangkat lunak GPES versi 4.9.005. Peralatan lain yang digunakan adalah pipet mikro, autoclave, dan mixing block MB - 102 produksi BIOER.

\section{Prosedur Kerja}

a. Optimasi Pengukuran $\mathrm{AgNO}_{3}$ dengan Metode VDDLA

Optimasi pengukuran $\mathrm{AgNO}_{3}$ dengan metode VDDLA dilakukan adalah potensial deposisi dari potensial -0,1 sampai -0,5 V; waktu deposisi dari 100 sampai 500 detik (tanpa proses pengadukan); dan laju perubahan potensial dari 0,01 sampai $0,1 \mathrm{~V} \cdot \mathrm{s}^{-1}$. Variabel tetap pada optimasi pengukuran adalah pembacaan potensial $-0,3$ sampai $0,7 \mathrm{~V}$; step potensial $0,0063 \mathrm{~V}$ dan amplitudo adalah $0,05 \mathrm{~V}$. Larutan yang digunakan pada prosedur optimasi ini yaitu $50 \mu \mathrm{M} \mathrm{AgNO}$ dalam $50 \% \mathrm{HNO}_{3}$ sebanyak $50 \mu \mathrm{L}$ dan buffer asetat 0,1 M pH 5,5 sebanyak $200 \mu \mathrm{L}$.

b. Modifikasi Immunoassay untuk Deteksi ASP Menggunakan Penanda Nanopartikel Emas - Perak Enhancer

Avidin dengan konsentrasi 1 sampai $10 \mu \mathrm{g} \cdot \mathrm{mL}^{-1}$ sebanyak $50 \mu \mathrm{L}$ dimasukkan ke dalam wellplate dan diinkubasi selama 12 jam pada suhu $4{ }^{\circ} \mathrm{C}$. Setelah proses inkubasi, wellplate dicuci dengan menggunakan $200 \mu \mathrm{L} 0,01 \mathrm{M}$ buffer fosfat $\mathrm{pH}$ 7,4 ditambah 0,05 
$\%$ (v/v) tween 20 (BPT) sebanyak 2 kali dan $200 \mu \mathrm{L}$ 0,01 M buffer fosfat pH 7,4 (BP) sebanyak 3 kali.

Wellplate Avidin ditambahkan $200 \mu \mathrm{L}$ Bovine serum albumin (BSA) dengan konsentrasi 0 sampai $4 \%(\mathrm{~m} / \mathrm{v})$ dalam BP (kondisi baru) dan diinkubasi selama 30 menit pada suhu $37{ }^{\circ} \mathrm{C}$ menggunakan shaker wellplate. Setelah proses inkubasi selesai, wellplate dicuci dengan menggunakan $200 \mu \mathrm{L}$ BPT sebanyak 2 kali dan $200 \mu \mathrm{L}$ BP sebanyak 3 kali.

Wellplate Avidin - BSA ditambahkan $50 \mu \mathrm{L}$ Peptida (peptida-TCEP) (kondisi baru) dan diinkubasi selama 15 sampai 90 menit pada suhu $37{ }^{\circ} \mathrm{C}$ menggunakan shaker wellplate. Setelah proses inkubasi selesai, wellplate dicuci dengan menggunakan $180 \mu \mathrm{L}$ BPT ditambah $20 \mu \mathrm{L}$ TCEP 10 mM sebanyak 2 kali dan $180 \mu \mathrm{L}$ BP ditambah $20 \mu \mathrm{L}$ TCEP $10 \mathrm{mM}$ sebanyak 3 kali.

Wellplate Avidin - BSA - peptida ditambahkan $50 \mu \mathrm{L}$ ASP dengan konsentrasi 0 500 ng.mL ${ }^{-1}$ dalam BP dan diinkubasi selama 1 jam pada suhu $37{ }^{\circ} \mathrm{C}$ menggunakan shaker wellplate. Setelah proses inkubasi selesai, wellplate dicuci dengan menggunakan $180 \mu \mathrm{L}$ BPT ditambah $20 \mu \mathrm{L}$ TCEP $10 \mathrm{mM}$ sebanyak 2 kali, $180 \mu \mathrm{L}$ BP ditambah $20 \mu \mathrm{L}$ TCEP 10 mM sebanyak 3 kali, dan $180 \mu \mathrm{L}$ TRIS 0,05 M ditambah $20 \mu \mathrm{L}$ TCEP $10 \mathrm{mM}$ sebanyak 2 kali.

Wellplate ditambahkan $50 \mu \mathrm{L}$ larutan nanopartikel emas + TRIS (1:1 (v/v)) dan diinkubasi selama 10 menit pada suhu ruang $\left(25^{\circ} \mathrm{C}\right)$. Wellplate dicuci dengan $200 \mu \mathrm{L} 0,5$ $\mathrm{M} \mathrm{NaNO}_{3}, 0,2 \%(\mathrm{v} / \mathrm{v})$ tween 20 dan 0,01\% (m/v) natrium dodesil sulfat (NTS) sebanyak 3 kali dan $200 \mu \mathrm{L} \mathrm{NaNO}_{3}$ 0,5 M sebanyak 2 kali. Wellplate dengan nanopartikel emas ditambahkan $50 \mu \mathrm{L}$ perak enhanced (larutan A : larutan $\mathrm{B}=1: 1(\mathrm{v} / \mathrm{v})$ ) dan direduksi selama 1 sampai 10 menit pada suhu ruang $\left(25^{\circ} \mathrm{C}\right)$ dalam ruang gelap. Wellplate dicuci dengan $200 \mu \mathrm{L}$ miliq water sebanyak 5 kali. Wellplate siap diukur dengan metoda VDDLA menggunakan elektroda SPE C-Ag/AgCl. Proses modifikasi immunoassay dapat dilihat pada Gambar 1.

\section{c. Pengukuran dengan metode VDDLA}

Wellplate termodifikasi ditambahkan $50 \mu \mathrm{L} \mathrm{HNO}_{3} 50 \%(\mathrm{v} / \mathrm{v})$ dan $200 \mu \mathrm{L}$ buffer asetat $0,1 \mathrm{M}$ pH 5,5, kemudian diaduk selama 2 menit. Elektroda SPE C-Ag/AgCl dicuci dengan air deionisasi dan dikeringkan menggunakan gas $\mathrm{N}_{2}$. Elektroda SPE C-Ag/AgCl dirangkai pada wellplate dan alat potensiostat dimana C (karbon) sebagai elektroda kerja dan $\mathrm{Ag} / \mathrm{AgCl}$ sebagai elektroda counter dan elektroda pembanding. Kondisi kerja yang diterapkan pada pengukuran dengan metoda VDDLA yaitu, potensial deposisi optimum, 
waktu deposisi optimum (tanpa proses stirring / pengadukan), potensial pembacaan $-0,3$ sampai $0,7 \mathrm{~V}$, laju perubahan potensial optimum, dan amplitude adalah 0,05 V.

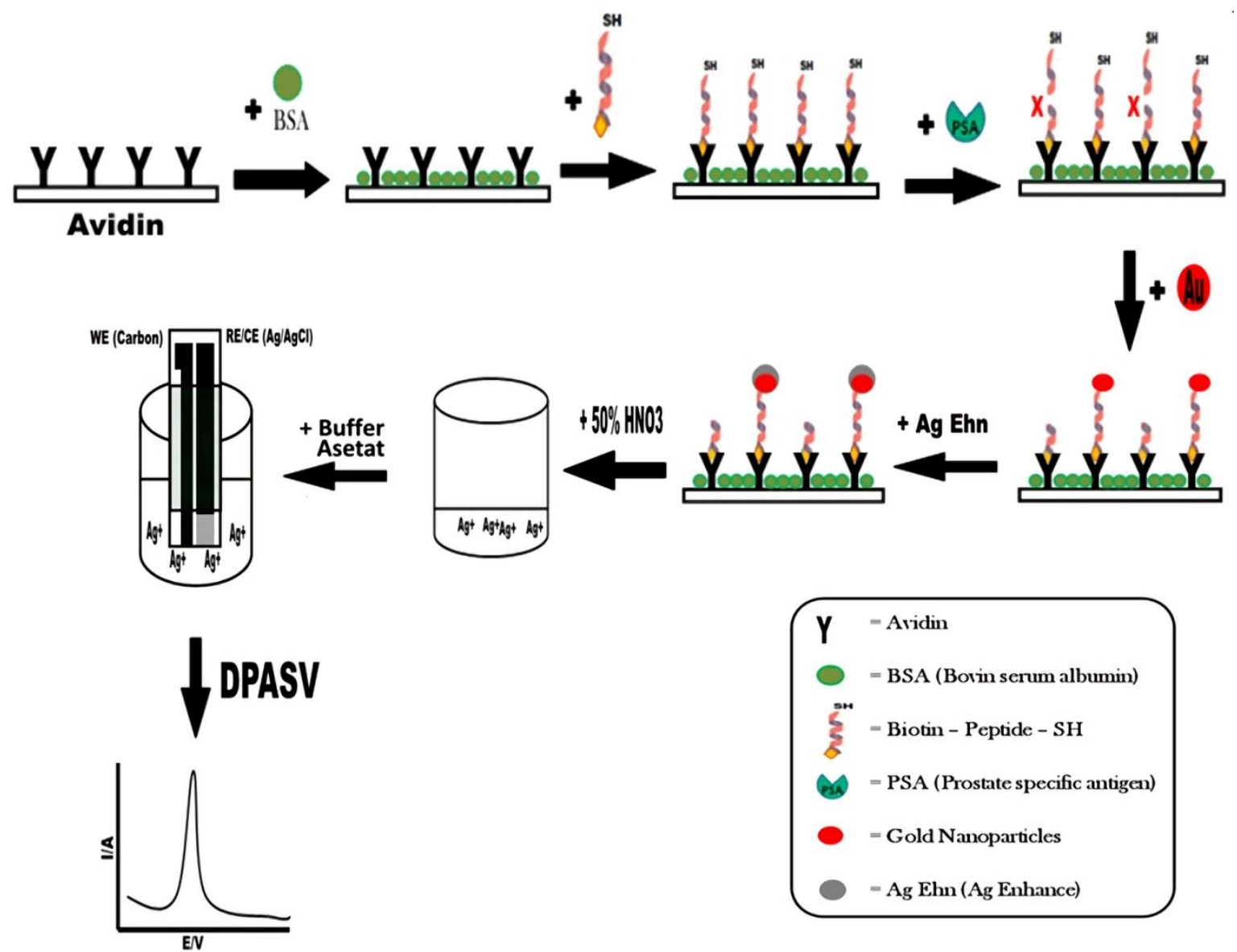

Gambar 1. Modifikasi immunoassay untuk deteksi ASP dengan metode VDDLA.

\section{PEMBAHASAN}

\section{Optimasi Pengukuran $\mathrm{AgNO}_{3}$ dengan Menggunakan Metode VDDLA}

Optimasi pengukuran $\mathrm{AgNO}_{3}$ menggunakan metode VDDLA dilakukan terhadap potensial deposisi, waktu deposisi, dan laju pembacaan. Pada optimasi potensial deposisi terjadi peningkatan arus yang dihasilkan sebanding dengan peningkatan potensial yang diberikan hingga mencapai titik jenuh $-0,4 \mathrm{~V}$ dan telah mencapai nilai optimal. Optimasi pengukuran yang kedua adalah optimasi waktu deposisi dan didapatkan nilai optimal pada waktu 300 detik. Optimasi pengukuran yang terakhir adalah optimasi laju pembacaan dan didapatkan optimal pada laju pembacaan $0,05 \mathrm{~V} . \mathrm{s}^{-1}$. Hasil pengukuran optimasi dapat dilihat pada Gambar 2. 


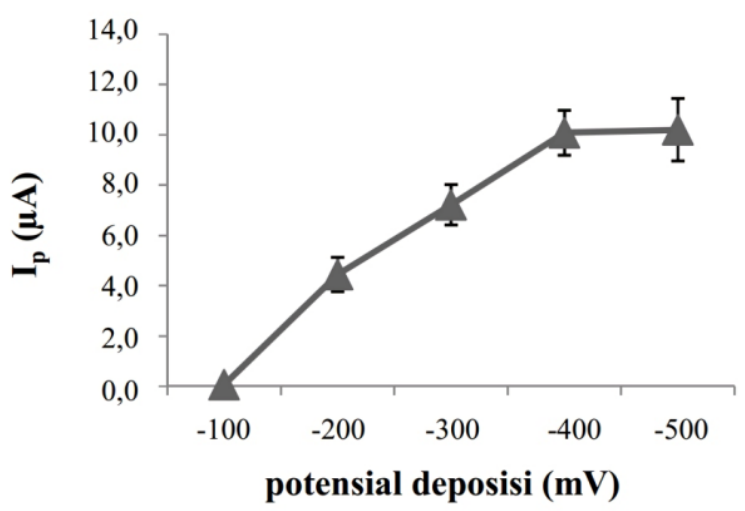

(a)

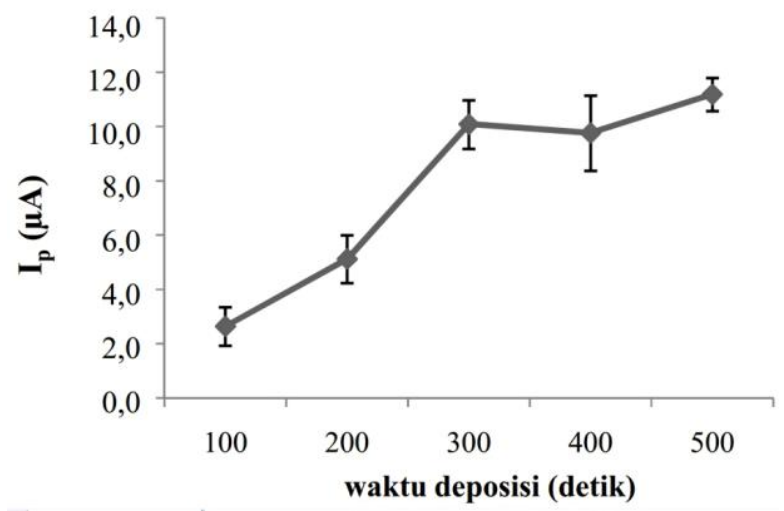

(b)

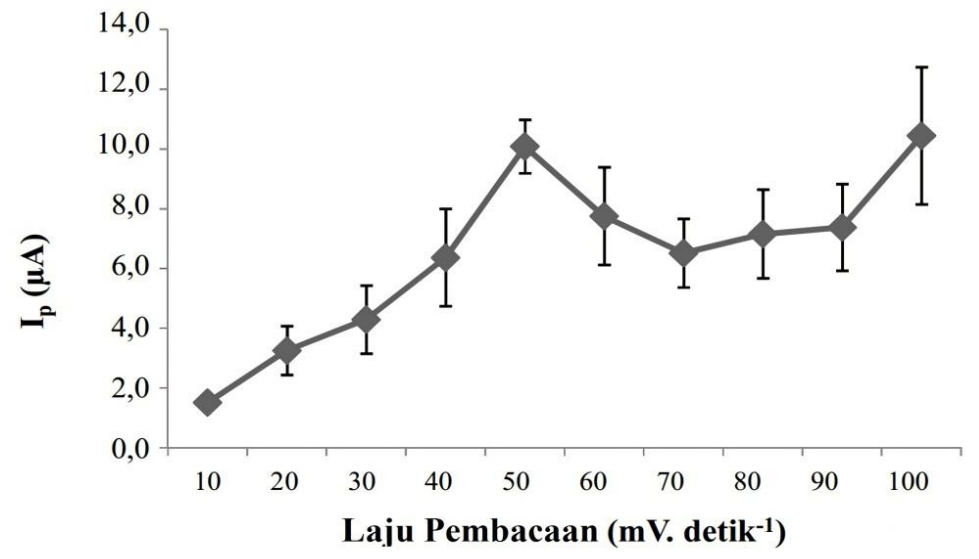

(c)

Gambar 2. Optimasi pengukuran $\mathrm{AgNO}_{3}$ dengan metode VDDLA : (a) Potensial Deposisi, (b) Waktu Deposisi, dan (c) Laju Pembacaan (scan rate).

\section{Modifikasi Immunoassay untuk Deteksi ASP dengan metode VDDLA}

a. Pengaruh Konsentrasi Avidin

Avidin merupakan suatu protein yang dapat terikat kuat pada dasar wellplate dengan permukaan maxisorp (hidrofilik). Avidin memiliki 4 sisi aktif yang dapat mengikat biotin dengan ikatan hidrogen. Konsentrasi avidin yang digunakan akan mempengaruhi jumlah biotin - peptida yang terikat. Pada penelitian ini, konsentrasi avidin yang dipelajari dari 1 - $10 \mu \mathrm{g} \cdot \mathrm{mL}^{-1}$, dimana konsentrasi avidin yang dibutuhkan berdasar pada perhitungan luas daerah dasar wellplate terhadap ukuran maksimal dari avidin adalah 2,6 $\mu \mathrm{g} \cdot \mathrm{mL}^{-1}$.

Pada konsentrasi ASP 0 ng. $\mathrm{mL}^{-1}$, peningkatan konsentrasi avidin akan meningkatkan jumlah mol biotin-peptida yang mengikat AuNP - AgEhn, sehingga akan meningkatkan arus puncak $\left(\mathrm{I}_{\mathrm{p}}\right)$. Namun pada hasil penelitian ini (Gambar 3), peningkatan konsentrasi avidin berbanding terbalik dengan arus puncak yang terukur (pada konsentrasi ASP 0 ng.mL ${ }^{-1}$ ). Arus puncak yang terukur pada konsentrasi avidin $1 \mu \mathrm{g} \cdot \mathrm{mL}^{-1}$ lebih tinggi dibandingkan pada konsentrasi avidin yang lain. Penurunan arus puncak pada peningkatan 
konsentrasi avidin ini disebabkan kerapatan susunan antibodi avidin pada dasar wellplate yang mengganggu pengikatan biotin-peptida untuk mengisi 4 sisi aktif avidin yang berdampak pada penurunan jumlah penanda AuNP - AgEhn yang terikat sehingga menurunkan arus puncak yang terukur. Penurunan arus puncak juga terjadi pada selisih arus $A g\left(I_{0}-I_{1}\right)$, yang diakibatkan oleh penurunan aktivitas ASP terhadap biotin - peptida (substrat) dan pengikatan penanda AuNp - AgEhn yang tidak maksimal. Berdasarkan hasil penelitian pada Gambar 3, peneliti menentukan konsentrasi avidin mencapai optimum pada konsentrasi 2,5 $\mu \mathrm{g} \cdot \mathrm{mL}^{-1}$, dengan selisih arus $\mathrm{Ag}\left(\mathrm{I}_{0}-\mathrm{I}_{1}\right)$ terukur maksimum yaitu 0,847 \pm $0,538 \mu \mathrm{A}$.

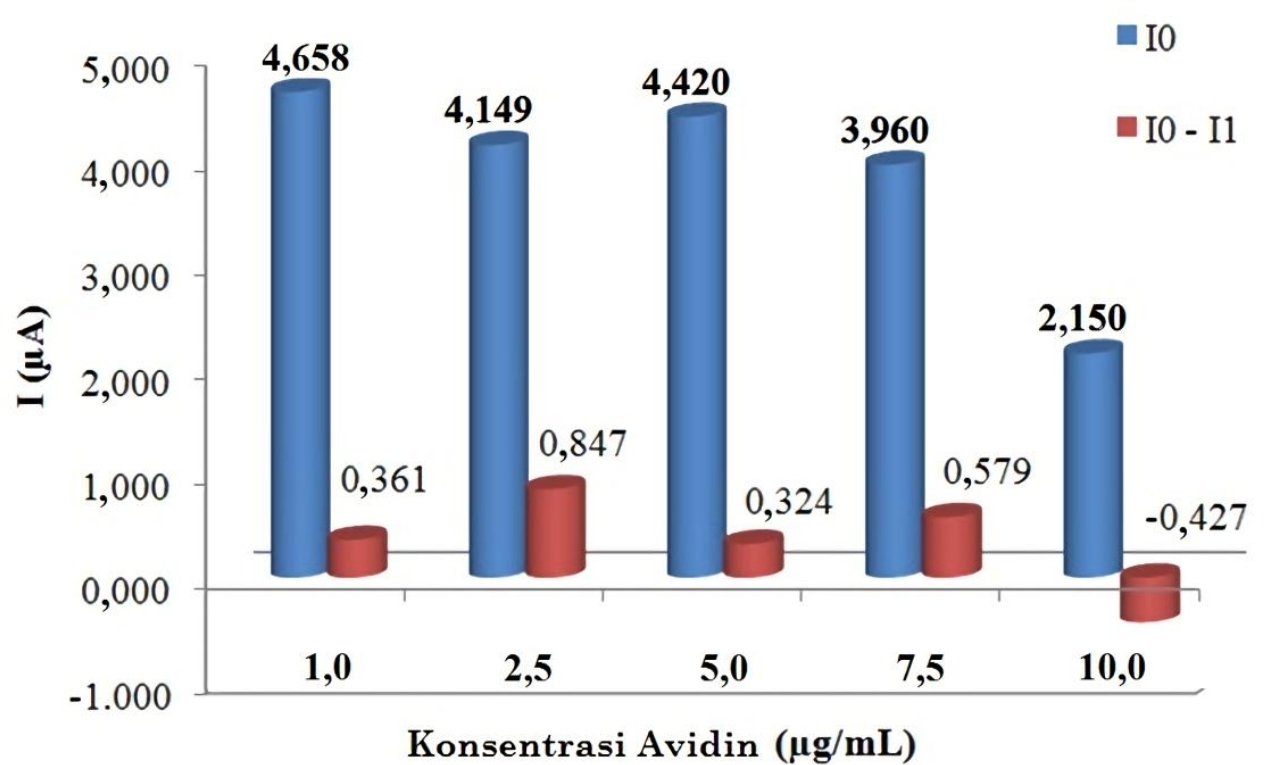

Gambar 3. Pengaruh konsentrasi avidin terhadap arus $\mathrm{Ag}$ yang terukur $\left(\mathrm{I}_{0}\right.$ untuk $0 \mathrm{ng} \cdot \mathrm{mL}^{-1}$ ASP dan $\mathrm{I}_{1}$ untuk 100 ng.mL $\left.\mathrm{L}^{-1} \mathrm{ASP}\right)$.

\section{b. Pengaruh Konsentrasi BSA}

Bovine serum albumin (BSA) (titik isoelektrik 4,7) pada metode immunoassay ini digunakan sebagai protein pendukung yang berfungsi untuk mengisi dasar wellplate yang tidak mengikat avidin (kosong). Pada penelitian ini, penggunaan BSA selain sebagai senyawa penghalang juga dapat meningkatkan stabilitas peptide dan enzim, namun tidak mengganggu proses immunoassay. Berdasarkan perhitungan ukuran BSA terhadap perkiraan ruang kosong pada wellplate yang tidak terisi oleh antibodi avidin, konsentrasi BSA yang dibutuhkan berkisar 1,5\% $\left(\mathrm{m} . \mathrm{v}^{-1}\right)$. 


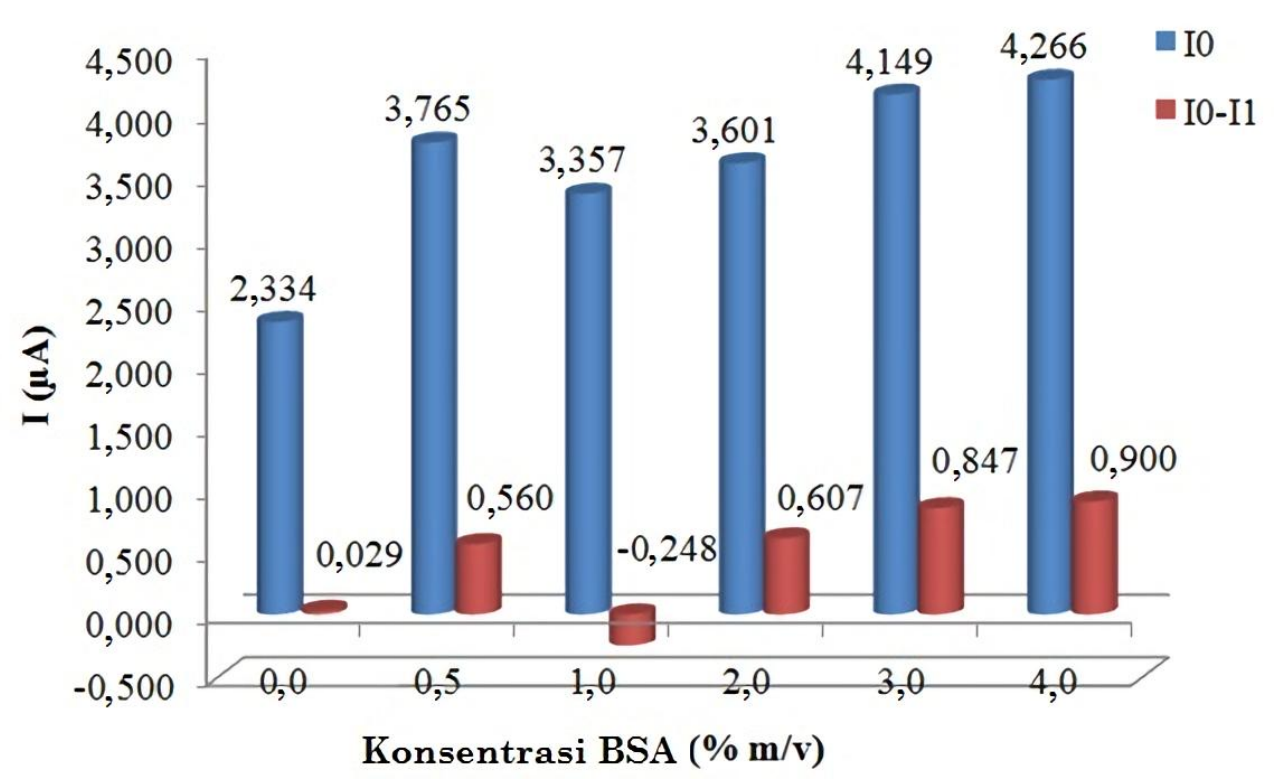

Gambar 4. Pengaruh konsentrasi BSA terhadap arus Ag yang terukur $\left(\mathrm{I}_{0}\right.$ untuk 0 ng.mL $\mathrm{mL}^{-1}$ ASP dan $\mathrm{I}_{1}$ untuk 100 ng.mL $\left.\mathrm{L}^{-1} \mathrm{ASP}\right)$.

Berdasarkan Gambar 4, peningkatan konsentrasi BSA berbanding lurus dengan arus Ag yang terukur (pada konsentrasi ASP 0 ng. $\mathrm{mL}^{-1}$ ). Hal ini dikarenakan BSA dapat berfungsi untuk menstabilkan protein yang terikat, sehingga biotin - peptida akan mengikat penanda AuNP - AgEhn dengan stabil dan spesifik. Kondisi peptida yang stabil terlihat pula pada nilai selisih arus $\operatorname{Ag}\left(\mathrm{I}_{0}-\mathrm{I}_{1}\right)$ yang mengalami peningkatan seiring dengan peningkatan konsentrasi BSA. Peningkatan konsentrasi BSA sebanding dengan dengan selisih arus $\left(\mathrm{I}_{0}-\mathrm{I}_{1}\right)$, namun nilai yang dihasilkan semakin tidak stabil sehingga mengakibatkan nilai standar deviasi yang tinggi. Pada penelitian ini, konsentrasi BSA mencapai nilai selisih arus yang stabil dengan nilai standar deviasi yang kecil adalah $2 \%$ dengan nilai selisih arus $\mathrm{Ag}\left(\mathrm{I}_{0}-\mathrm{I}_{1}\right)$ 0,607 $\pm 0,156 \mu \mathrm{A}$.

\section{c. Pengaruh Waktu Inkubasi Peptida}

Peptida yang digunakan sebagai substrat memiliki gugus tiol (-SH) yang berasal dari Mpa. Menurut penelitian Al-Akraa et al. (2013), gugus tiol mudah mengikat nanopatikel emas sebagai penanda secara kovalen. Waktu inkubasi peptida tergantung pada laju reaksi biotin - peptida untuk berikatan hidrogen dengan sisi - sisi aktif avidin. Peningkatan waktu inkubasi peptida akan mempengaruhi jumlah peptida yang terikat pada avidin, namun lama waktu inkubasi juga dapat menyebabkan ikatan peptida mengalami denaturasi dan gugus tiol pada ujung biotin - peptida mengalami oksidasi sehingga membentuk ikatan kovalen disulfida (S-S). Ikatan disulfida yang terbentuk akan 
mengganggu proses pengikatan penanda AuNP - AgEhn sehingga menurunkan arus puncak yang terukur.

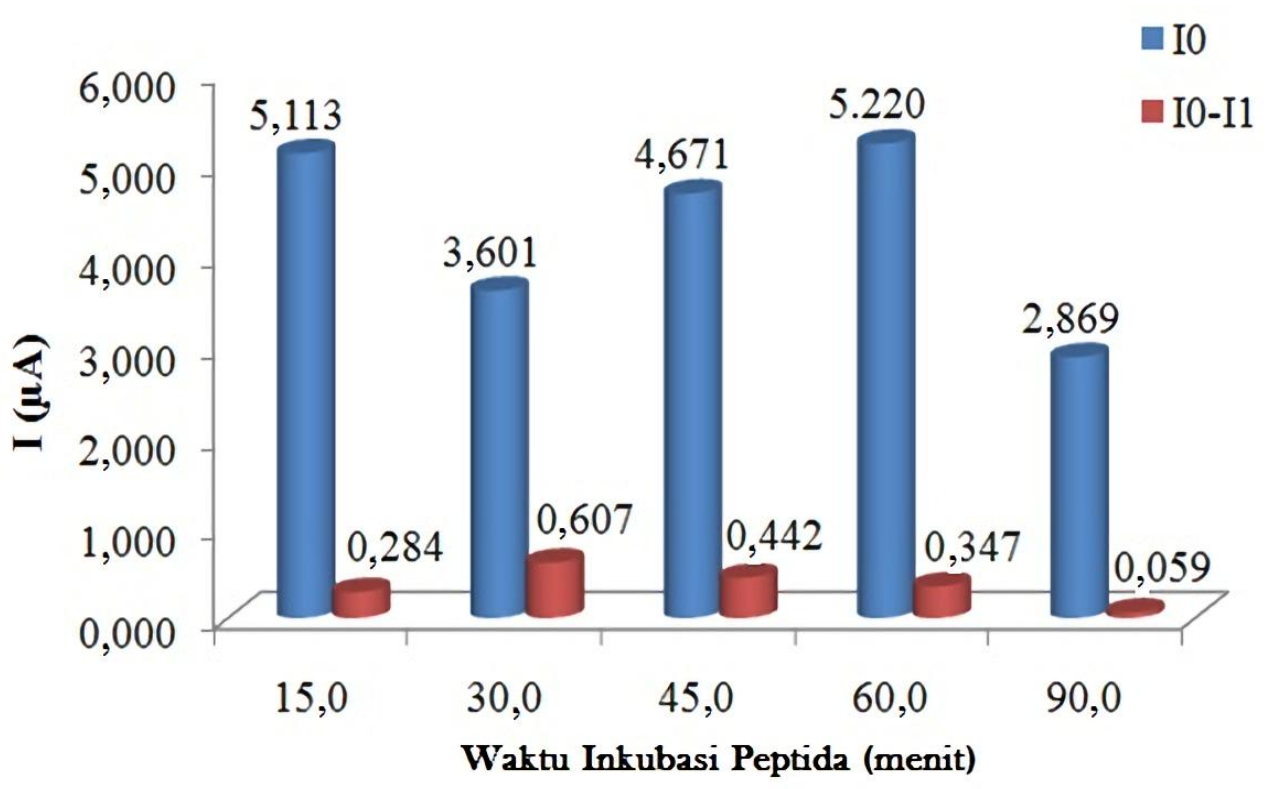

Gambar 5. Pengaruh waktu inkubasi peptida terhadap arus Ag yang terukur $\left(\mathrm{I}_{0}\right.$ untuk 0 ng.mL ${ }^{-1}$ ASP dan $\mathrm{I}_{1}$ untuk 100 ng.mL ${ }^{-1}$ ASP).

Pada penelitian ini, waktu inkubasi berbanding lurus dengan arus Ag yang terukur (pada konsentrasi ASP 0 ng.mL $\left.\mathrm{m}^{-1}\right)($ Gambar 5). Hal ini disebabkan waktu inkubasi peptida sebanding dengan jumlah substrat yang terikat pada sisi - sisi aktif avidin, sehingga mempengaruhi peningkatan arus Ag yang dihasilkan. Pada waktu inkubasi 60 menit, arus puncak $\left(\mathrm{I}_{\mathrm{p}}\right.$ ) yang terukur memiliki nilai tertinggi (pada konsentrasi ASP $0 \mu \mathrm{g} \cdot \mathrm{mL}^{-1}$ ) yang mengindikasikan biotin - peptida telah maksimum berikatan dengan sisi-sisi aktif avidin. Namun selisih arus tertinggi terjadi pada waktu inkubasi peptide 30 menit. Pada penelitian ini, waktu inkubasi optimum peptida pada penentuan ASP dengan metode ini adalah 30 menit dengan nilai arus yang terukur hanya $3,601 \mu \mathrm{A}$ dannilai selisih arus $\operatorname{Ag}\left(\mathrm{I}_{0}-\mathrm{I}_{1}\right)$ terukur maksimum dengan standar deviasi (SD) kecil yaitu 0,607 $\pm 0,156 \mu \mathrm{A}$.

\section{d. Pengaruh Waktu Deposisi Perak Enhancer}

Perak enhancer (AgEhn) adalah senyawa garam perak yang direduksi menggunakan senyawa pereduksi hidroquinon dan dapat terdeposisi pada permukaan emas. Waktu deposisi AgEhn akan mempengaruhi jumlah Ag yang tereduksi. Menurut Morphew et al. (2008), bahwa semakin lama waktu deposisi AgEhn pada permukaan nanopartikel emas maka akan semakin banyak ion Ag yang terdeposisi pada permukaan. Jumlah Ag yang terdeposisi pada permukaan nanopartikel emas berbanding lurus dengan arus Ag yang terbaca. 


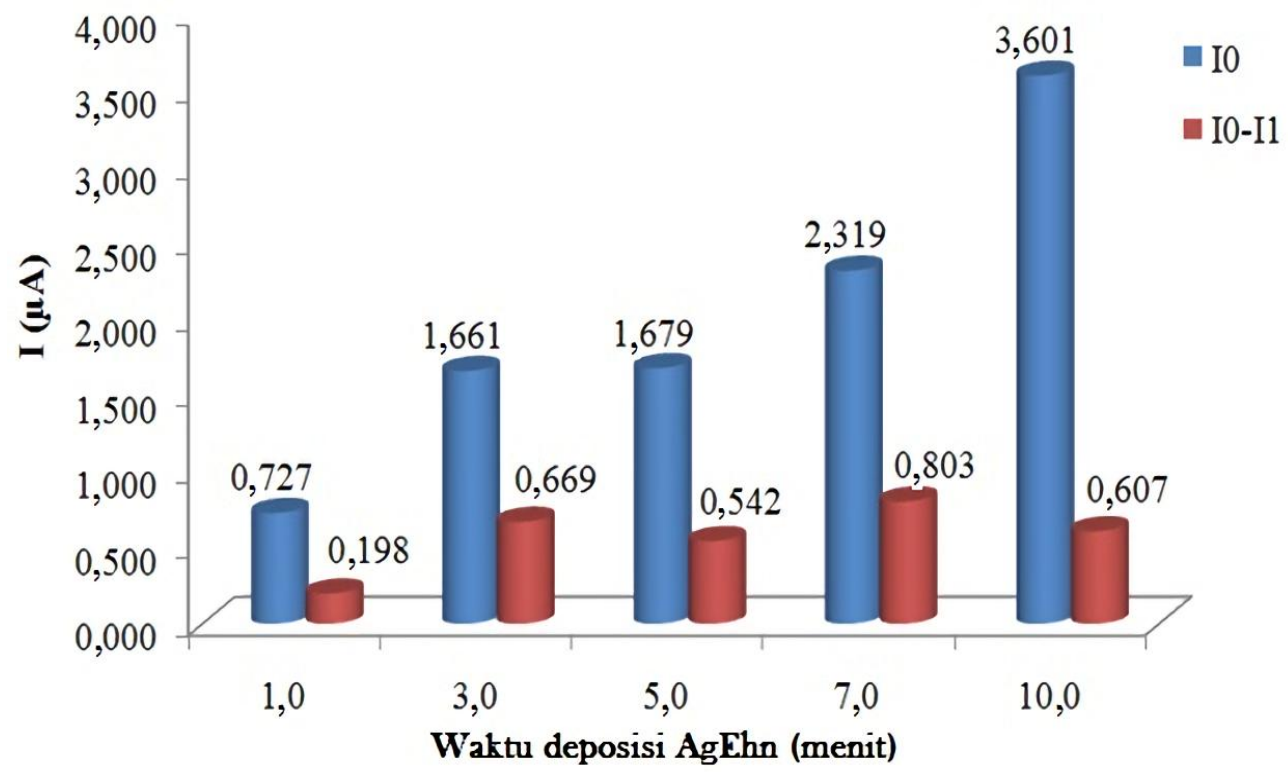

Gambar 6. Pengaruh waktu deposisi AgEhn terhadapat arus Ag yang terukur $\left(\mathrm{I}_{0}\right.$ untuk 0 ng.mL ${ }^{-1}$ ASP dan $\mathrm{I}_{1}$ untuk 100 ng. $\mathrm{mL}^{-1}$ ASP)

Pada penelitian ini, AgEhn digunakan sebagai penanda yang akan dideteksi dengan metode VDDLA. Pengaruh waktu deposisi AgEhn dilakukan pada 1 - 10 menit dalam ruang gelap. Berdasarkan Gambar 6, waktu deposisi AgEhn berbanding lurus dengan arus Ag yang terukur (pada konsentrasi AuNP tetap dan konsentrasi ASP 0 ng.mL ${ }^{-1}$ ). Hal ini disebabkan jumlah ion $\mathrm{Ag}^{+}$yang terdeposisi pada permukaan emas menjadi $\mathrm{Ag}_{(\mathrm{s})}$ semakin meningkat. Waktu deposisi optimum AgEhn untuk penentuan ASP dengan metode ini adalah 3 menit, dimana jumlah Ag yang terdeposisi dapat memberikan nilai selisih arus Ag $\left(\mathrm{I}_{0}-\mathrm{I}_{1}\right)$ yang cukup tinggi dengan standar deviasi $(\mathrm{SD})$ yang rendah yaitu $0,669 \pm 0,124$ $\mu \mathrm{A}$.

\section{Penentuan ASP dengan Metode VDDLA}

Penentuan ASP dengan menggunakan AuNP - AgEhn sebagai senyawa penanda dilakukan pada konsentrasi PSA $0 ; 1 ; 10 ; 50 ; 100 ; 250$; dan 500 ng.mL $\mathrm{mL}^{-1}$. ASP bekerja secara enzimatis memotong peptida, sehingga peningkatan konsentrasi ASP akan menurunkan jumlah substrat yang dapat mengikat AuNP - AgEhn akibat adanya pemotongan rantai peptida yang memiliki gugus tiol $(-\mathrm{SH})$. Untuk mengetahui jumlah peptida yang terpotong oleh ASP maka dapat ditentukan dengan menghitung selisih arus Ag $\left(\mathrm{Ip}_{0}-\mathrm{Ip}_{\mathrm{i}}\right)$. Kondisi yang digunakan pada proses immunoassay untuk penentuan ASP ini adalah konsentrasi avidin 2,5 $\mu \mathrm{g} \cdot \mathrm{mL}^{-1}$, konsentrasi BSA $2 \%$, waktu inkubasi substrat (biotin - peptida) 30 menit, dan waktu deposisi AgEhn 3 menit. Berdasarkan Gambar 7(a), peningkatan konsentrasi ASP menyebabkan penurunan arus Ag yang disebabkan oleh 
peningkatan jumlah peptida yang terpotong sehingga jumlah AuNP - AgEhn yang terikat juga semakin sedikit. Kurva konsentrasi ASP terhadap selisih arus puncak (Gambar 7 (b)) pada rentang konsentrasi ASP 1 - 500 ng. $\mathrm{mL}^{-1}$ memberikan persamaan linier $\mathrm{I}(\mu \mathrm{A})=$ 0,003 [ASP] $+0,173$ dengan regresi linier $=0,940$, sehingga didapatkan sensitivitas penentuan ASP dengan metode ini adalah 0,003 $\mu \mathrm{A} / \mathrm{ng} \cdot \mathrm{mL}^{-1}$. Penentuan batas deteksi (Limit of detection / LoD) pada penelitian ini adalah 3 kali dari simpangan baku dibagi dengan kemiringan pada kurva konsentrasi ASP terhadap selisih arus puncak, sehingga didapatkan batas deteksi sebesar 152,204 ng.mL ${ }^{-1}$.

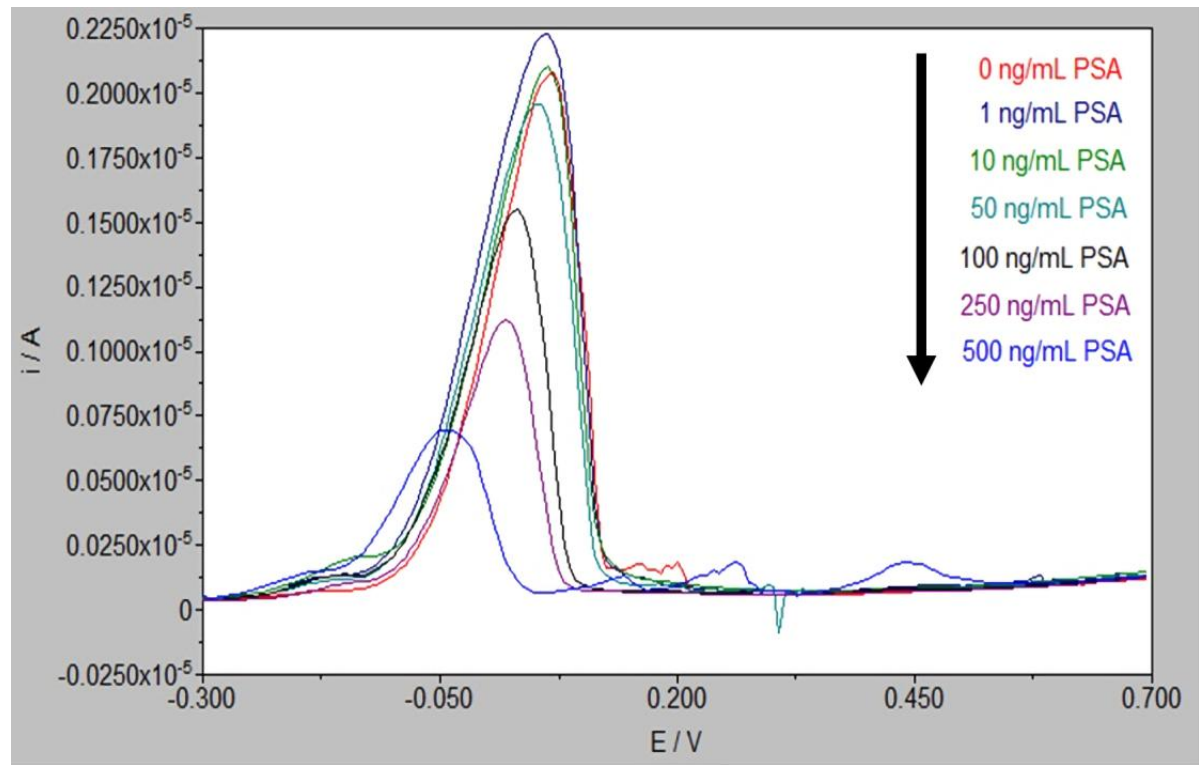

(a)

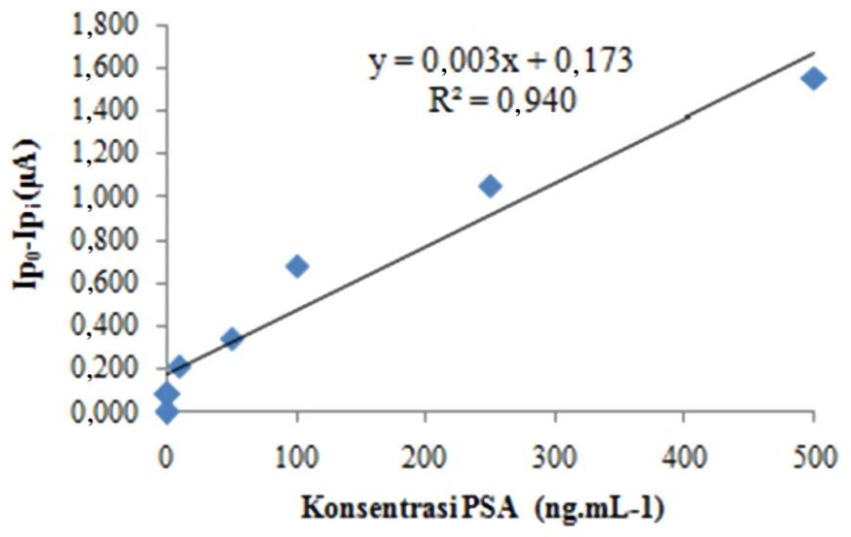

(b)

Gambar 7. (a) Voltamogram VDDLA pada konsentrasi ASP 1 sampai $500 \mathrm{ng} / \mathrm{mL}$ terhadap Arus Ag (E vs Ag/AgCl), (b) Kurva kalibrasi konsentrasi PSA 1 sampai 500 ng/mL terhadap selisih Arus Ag 


\section{KESIMPULAN}

Penentuan ASP dengan metode VDDLA dapat dilakukan dengan baik dan memberikan batas deteksi 152,204 ng.mL ${ }^{-1}$. Nilai batas deteksi yang diberikan masih melebihi batas normal konsentrasi ASP dalam darah manusia yaitu 4 ng.mL ${ }^{-1}$, sehingga diperlukan pengembangan metode dengan menggunakan jenis elektroda kerja selain SPE karbon/Ag/AgCl dan metode pengukuran voltametri yang lebih selektif dan sensitif.

\section{UCAPAN TERIMAKASIH}

Penelitian ini didukung oleh proyek National Research University dari Thailand, King Mongkut's University of Technology Thonburi - Thailand, dan Universitas Brawijaya Indonesia.

\section{DAFTAR PUSTAKA}

Al-Akraa, I. M., Mohammad, A. M., El-Deab, M. S., and El-Anadouli, B. E., 2013. SelfAssembling of Gold Nanoparticles Array for Electro-Sensing Applications. International Journal of Electrochemical Science 8, 458 - 466.

Ambrosi, Adriano, 2007. The Application of Nanomaterials in Electrochemical Sensors and Biosensors. School of Chemical Sciences, Dublin City University. Ireland.

Cai, H., Wang, Y., He, P., and Fang, Y., 2002. Electrochemical Detection of DNA Hybridization Based on Silver - Enhanced Gold Nanoparticle Label. Analytical Chimica Acta 469 (2), 165 - 172.

Cui, R., Huang, H., Yin, Z., Gao, D., and Zhu, J. J., 2008. Horseradish Peroxidase functionalized Gold Nanoparticle Label for Amplified Immunoanalysis Based on Gold Nanoparticles / Carbon Nanotubes Hybrids Modified Biosensor. Biosensors and Bioelectronics 23 (11), 1666 - 1673.

Denmeade, S. R., Lou, W., Lövgren, J., Malm, J., Lilja, H., and Isaacs, J. T., 1997. Specific and Efficient Peptida Substrates for Assaying The Proteolytic Activity of Prostate Specific Antigen. Cancer Research 57, 4924-4930.

Kang, J., Li, X., Wu, G., Wang, Z., and Lu, X., 2007. A New Scheme of Hybridization Based on The $\mathrm{Au}_{\text {nano }}$ - DNA Modified Glassy Carbon Electrode. Analytical Biochemistry 364 (2), 165 - 170.

Lei Zhu, 2009. Development of Novel Assays for Measuring Different Molecular Forms of Prostate Specific Antigen. Department of Clinical Chemistry. University of Helsinki. Finland.

Liang, R., Qui, J., and Cai, P., 2005. A Novel Amperometric Immunosensor Based on Threedimensional Sol - Gel Network and Nanoparticle Self - Assemble Technique. Analytical Chimica Acta 534 (2), 223 - 229. 
Liu, X., Wu, H., Zheng, Y., Wu, Z., Jiang, J., Shen, G., and Yu, R., 2010. A Sensitive Electrochemical Immunosensor for $\alpha$-Fetoprotein Detection with Colloidal GoldBased Dentritical Enzyme Complex Amplification. Electroanalysis 22, 244 - 250.

Lu, L. P., Wang, S. Q., and Lin, X. Q., 2004. Fabrication of Layer - by - Layer Deposited Multilayer Films Containing DNA and Gold Nanoparticle for Norepinephrine Biosensor. Analytica Chimica Acta 519 (2) 161 - 166.

Morphew, M., He, W., Bjorkman, P.J., and Mcintosh, J.R., 2008. Silver Enhancerment of Nanogold Particles during Freeze Substitution for Electron Microscopy. Journal of Microscopy 230, 263-267.

Niemelä, P., Lövgren, J., Karp, M., Lilja, H., and Pettersson, K., 2002. Sensitive and Specific Enzymatic Assay for the Determination of Precursor Forms of Prostate specific Antigen after an Activation Step. Clinical Chemistry 48 (8), 1257-1264.

Selvaraju, T., Das J., Han S. W., and Yang H., 2008. Ultrasensitive Electrochemical Immunosensing Using Magnetic Beads and Gold Nanocatalysts. Biosensors and Bioelectronics 23 (7), $932-938$.

Suaifan, G. A. R. Y., Esseghaier, C., Ng, A., and Zourob, M., 2012. Wash-Less and Highly Sensitive Assay for Prostate Specific Antigen Detection. Analyst 137, 5614 - 5619.

Wu, C. C., Pan, T. M., Wu, C. S., Yen L. C., Chuang, C. K., Pang, S. T., Yang, Y. S., and Ko, F. H., 2012. Label-free Detection of Prostate Specific Antigen Using a Silicon Nanobelt Field-effect Transistor. International Journal of Electrochemical Science 7, 4432-4442.

Wu, L., Chen, J., Du, D., and Ju, H., 2006. Electrochemical Immunoassay for CA125 Based on Cellulose Acetate Stabilized Antigen/Colloidal Gold Nanoparticles Membrane. Electrochimica Acta. 51 (7), 1208 - 1214.

Zhao, N., He, Y., Mao, X., Sun, Y., Zhang, X., Li, C.Z., Lin, Y., and Liu, G., 2010. Electrochemical Assay of Active Prostate Specific Antigen (PSA) Using FerroceneFunctionalized Peptide Probes. Electrochemistry Communications 12, 471-474.

Zheng, J., Feng, W., Lin, L., Zhang, F., Cheng, G., He, P., and Fang, Y., 2007. A New Amplification Strategy for Ultrasensitive Electrochemical Aptasensor with Network-Like Thiocyanuric Acid-Gold Nanoparticles. Biosensors and Bioelectronics 23 (3), 341 - 347.

Zhu, L., Leinonen, J., Zhang, W. M., Finne, P., and Stenman U.H., 2003. Dual-Label Immunoassay for Simultaneous Measurement of Prostate Specific Antigen (PSA) - 1 -Antichymotrypsin Complex Together with Free or Total PSA. Clinical Chemistry 49 (1), 97-103. 